\title{
The Effect of Job Insecurity on Turnover Intention Through Work Satisfaction in Employees of Pt Telkom Access Singaraja
}

\author{
Komang Krisna Heryanda* \\ Management Department Ganesha University of Education Singaraja, Indonesia
}

\section{A R T I C L E I N F O}

Article history:

Received 19 May 2019

Received in revised form

16 June 2019

Accepted 15 July 2019

Available online 29 August 2019

Keywords:

job insecurity, job

satisfaction, turnover

intention

\begin{abstract}
A B S T R A C T
This study aimed at examining the effect of (1) job satisfaction mediating the effect of job insecurity on turnover intention, (2) job insecurity on job satisfaction, (3) job insecurity on turnover intention, (4) job satisfaction on turnover intention. The method of data collection was done by observation, interviews and questionnaires by using a Likert scale. The analysis technique used was path analysis (path anaylsis) with the SPSS 17.0 for windows program. The analysis shows that (1) job satisfaction was able to mediate partially the effect of job insecurity on turnover intention, (2) job insecurity had a negative and significant effect on job satisfaction, (3) job insecurity had a positive and significant effect on turnover intention, (4) satisfaction work had a negative and significant effect on turnover intention.
\end{abstract}

\footnotetext{
* Corresponding author.

E-mail addresses: krisna.heryanda@gmail.com (Komang Krisna Heryanda)
} 


\section{Introduction}

Human resources (HR) has a very strategic position in the organization, it means that the human element plays an important role in carrying out all organizational activities. Likewise, in the context of business organizations or companies, the company's back and forth is determined by the existence of its human resources. In order to achieve the goals, it is very important for companies to pay attention and manage their employees well. If it is not, then there will be various problems that can disrupt the activities in the company. One form of employee attitude that often arises due to the ineffectiveness of HR management owned by the company is the desire to move work (turnover intention) which leads to the employee's decision to leave work (turnover). This opinion is supported by Elmi (2018: 195), one of the efforts to achieve company goals is to minimize employee turnover by paying attention to all factors that lead to the desire of employees to move (turnover intention).

Turnover intention is something that is not desired by a company. The high level of turnover intention will have a negative impact on the company which can create instability and uncertainty about the condition of employees. The main thing that will become Sunyoto (2012: 214) states that the cause of the desire to change jobs is dissatisfaction with the workplace now. Employees who feel dissatisfied with the work have done cause the employee to have a high desire to leave the company. Job satisfaction can make employees work better and be able to survive in the company. This opinion is supported by Robbins and Timothy (2015: 54) who says that lower job satisfaction is a predictor of employees leaving work.

To get high job satisfaction, there is a need for security in the company. If the company has a high job insecurity, then job satisfaction will be low and the employee turnover intention will be high. Job insecurity is a psychological condition of an employee who feels threatened or worried about the continuity of his work in the future. Employees who feel worried, nervous when working in the company will cause the employee to have an unpleasant feeling on his job and have an impact on the lack of job satisfaction of employees and lead to the desire to leave the turnover intention company. This opinion is supported by Mobley (2011), several factors that influence turnover intention including job insecurity and job satisfaction, employees who have high job insecurity causes low job satisfaction and will have an impact on turnover intention.

PT Telkom Access Singaraja is engaged in the business of providing construction services and managing network infrastructure. In addition to the installation of broadband access networks, other services provided by PT Telkom Singaraja Access are Network Terminal Equipment (NTE), as well as the Operations and Maintenance Services (Operation \& Maintenance) of the Access network. At present PT Telkom Access Singaraja houses 7 urban areas in Bali, namely Singaraja, Tabanan, Gianyar, Negara, Amlapura, Semarapura, and Bangli. PT Telkom Access Singaraja has 275 employees consisting of 268 contract employees and 7 permanent employees. Every year the employee turnover rate at PT Telkom Singaraja Access is very high, especially for employees of PT Telkom Access the Singaraja area. At present PT Telkom active employees access the Singaraja area are 112 employees consisting of 2 permanent employees and 110 contract employees. PT Telkom Access the Singaraja area has a high turnover rate. This can be seen in Table 1

Table 1. PT Telkom Employee Turnover Rates Access the Singaraja area for the period 2016 - September 2018

\begin{tabular}{cccc}
\hline Year & $\begin{array}{l}\text { Average Number of } \\
\text { Employees } \\
\text { (person) }\end{array}$ & $\begin{array}{l}\text { Number of Employees who } \\
\text { leave }\end{array}$ & $\begin{array}{c}\text { Presentage of employees } \\
\text { who leave (\%) }\end{array}$ \\
\hline 2016 & 104 & 22 & 21,15 \\
2017 & 110 & 36 & 32,73 \\
2018 & 126 & 28 & 22,22 \\
\hline
\end{tabular}

Source : HRD PT Telkom Akses area Singaraja, 2018

Based on the data in table 1, it can be seen that in 2016 until September 2018 there was a high employee turnover rate. Harris (in Alfresia, 2016) states that the standards of employee turnover that can be tolerated at each company was various, but if the turnover rate reached more than $10 \%$ per year was too high according to many standards. From the data above, the employee turnover that occurs at PT Telkom Access the Singaraja area is high because it exceeds the tolerable limits. High turnover can be used as an indication of high turnover intention in the company, because before the turnover, the employees are experience turnover intention. This opinion is supported by Elmi (2018: 352) intention is the best 
single predictor of behavior that will be done by someone, thus turnover intention is the best predictor of symptoms or behavior of turnover.

Based on interviews conducted with PT Telkom's Human Resources Development (HRD) Access the Singaraja area, the reason of employees to leave the company caused by the employees get new jobs that are considered better than their previous jobs, do not want to be moved to work locations outside Singaraja so they leave the company, natural selection (employees are not strong with the work given) and many employees leave the company without giving clear reasons. Whereas based on interviews conducted with several employees who have left, the reason employees leave the company is due to the employment status as contract employees. Employees feel threatened and worried about the continuity of work in the future. In addition, employees feel the salary provided is not comparable with workload given. Even though the employee gets a salary according to the Buleleng Regency standard salary, but according to him it is not worth the workload they get during work. According to him, the workload given is too high, especially employees who work in the engineering department, so that employees feel less happy with the work provided. In addition, the selection of permanent employees conducted twice a year is considered very difficult for employees to achieve, due to intense competition and proven to date the company only has 2 permanent employees. This makes employees have low job satisfaction so they decide to leave the company and find a better job than their previous job.

The high turnover intention has become a serious problem experienced by PT Telkom Singaraja Access area, where the negative impact that is felt is the difficulty of getting the quality and capabilities that are in accordance with the qualifications set by the company and it takes time and costs to recruit new employees. Therefore, it is important for PT Telkom to access the Singaraja area to find out the employee turnover rate.

Based on interviews conducted with 10 employees who are still active, 7 of them have the desire to leave the company due to their employment status as contract employees where employees feel threatened, anxious, and lack of guarantees from the company because the contract system will make employees lost his job after the contract period is completed. Somehow, the employee decides to find a better job and leaves the company before the contract expires. In addition, job satisfaction that is felt less by employees is caused by salary, the job itself, and colleagues. The salary they receive is not worth the workload they get. The high workload, especially employees of the PSB technicians (new pairs), maintenance (maintenance) and assurance (repair) make employees feel tired while working so that the job becomes unpleasant. In addition, cooperation with coworkers is felt to be lacking because in completing the work, especially in a team, there must be employees who only want to work optimally when supervised by TL (team leader). Then, if is not monitored, employees will arrive late to the work location, lazing around, and don't want to spend fully.

Based on the above phenomena, researchers see that it is necessary to conduct a study entitled "The Effect of Job Insecurity on Turnover Intention through Job Satisfaction in PT Telkom Employees Access the Singaraja area". Based on the background above, the formulation of the problem in this study are as follows (1) How job satisfaction mediates the effect of job insecurity on turnover intention on employees of PT Telkom Singaraja area access, (2) How does job insecurity affect job satisfaction in PT Telkom employees Access to the Singaraja area, (3) How does the effect of job insecurity on turnover intention on employees of PT Telkom Singaraja area access, (4) How does the effect of job satisfaction on turnover intention on PT Telkom employees access the Singaraja area.

Based on the background and formulation of the problem above, the objectives of this study are as follows (1) To find out job satisfaction mediates the effect of job insecurity on turnover intention on employees of PT Telkom Singaraja Access area, (2) To determine the effect of job insecurity on job satisfaction to employees of PT Telkom Singaraja Access area, (3) To find out the effect of job insecurity on turnover intention on employees of PT Telkom Singaraja Access area, (4) To determine the effect of job satisfaction on turnover intention at PT Telkom Access Singaraja area.

Employees who feel job insecurity at work will have low job satisfaction. If the problem of work insecurity in continuous work is faced by employees, it will stimulate the emergence of the desire to move work or turnover intentions. According to Sverke et al (2014) in the short term job insecurity has an effect on job satisfaction and in the long term, it will affect turnover intention. This means that, if the problem of work insecurity in continuous work faced by employees, it will have an effect on employee job satisfaction and if it continues to occur it will stimulate the emergence of the desire to move work or turnover intentions.

This is supported by research conducted by Setiawan (2016). In his research, it was found that partially job satisfaction mediated the effect of job insecurity on turnover intention on employees of Legian village hotel. This is reinforced by the research conducted by Devi (2015) on his research on contract employees at Bali Dynasty Resort revealing that job satisfaction plays a role in job insecurity affecting turnover intention both directly and indirectly. 
Job insecurity becomes a very important to guarantee the job. Employees who feel insecure in working will have an impact on low job satisfaction. This opinion is supported by Sverke et al (2014) according to which job insecurity has an effect on increasing employee dissatisfaction at work. This means that if employees have high job insecurity, employee job satisfaction will decrease. Employees who have job insecurity towards the continuity of their work tend to feel dissatisfied if it is compared to those who feel the certainty of the future of their work.

This opinion is supported by research conducted by Nurhadi (2017) which states that job insecurity has a negative and significant influence on job satisfaction at PT Karya Mitra Budi Sentosa. This is reinforced by research conducted by Yasadipura (2017) which states that job insecurity has a negative and significant effect on job satisfaction on Contract Employees of PT. Wico Interna, Singaraja-Bali.

If the problem of job insecurity (job insecurity) in working continuously faced by employees, it will stimulate the emergence of the desire to move or turnover intentions. According to Suhartono (2007: 61) if employees who experience job insecurity are increasing because of the instability of their employment status, which is only as a contract employee, it can trigger high turnover intention of employees that occur in a company. According to Mudiartha et al. (2001: 252) if work conditions are not safe, there will be a high turnover intention. Job insecurity is a very important guarantee of employment, so employees who feel insecure and threatened at work are more likely to wish to change jobs.

This opinion is supported by research conducted by Hanafiah (2014) where in his research found results that, work insecurity has a positive and significant effect on intention to move work to employees of PT. Buma Suara Village, Sambaliung District, Berau District. This is reinforced by research conducted by Septiari (2017) which states that job insecurity has a positive and significant impact on employee turnover at Hotel Asana Agung Putra Bali.

Employees who have low job satisfaction will have a high desire to leave the company, conversely if employees have high job satisfaction then employees will have the desire to stay in the company. This opinion is supported by Martoyo (2007: 77) one of the things that influences employees' intention to leave the organization is the level of job satisfaction. Employees who have low job satisfaction will have an impact on turnover intention. This opinion is supported by Robbins and Timothy (2015: 54) who says that lower job satisfaction is a predictor for leaving work. Employees who feel dissatisfied with the work cause the employee to have a high desire to leave the company.

This is supported by research conducted by Hanafiah (2014) where in his research found results that job satisfaction negatively and significantly influences the intention to move work to employees of PT. Buma Suara Village, Sambaliung District, Berau District. This is reinforced by research conducted by Prabawa (2017) which states that job satisfaction has a negative and significant effect on turnover intention at Grand Mirage Resort \& Thalasso Bali.

\section{Methods}

This study used a quantitative causal design. According to Sugiyono (2014: 56) causal research is a study that seeks the relationship between one variable with another variable that has a causal relationship. Quantitative causal research design can be done with the following steps: (1) formulating the problem, (2) reviewing the theory, (3) formulating a hypothesis, (4) collecting data, (5) analyzing the data, and (6) making conclusions and suggestion.

The subjects in this study were employees of PT Telkom Access the Singaraja area. While the objects in this study were job insecurity (X), job satisfaction (Z), and turnover intention (Y). To determine the sample to be used, researchers used the Slovin formula and obtained a sample of 88 people. The sampling technique in this study used incidental sampling techniques. The data collection methods used in this study were as follows (1) observation, carried out mainly to find out a general description of the subject and object that will be carried out the research, (2) interviews, carried out during initial observation with the company namely HRD (Human Resource Department) and some active employees at PT Telkom Akses North Bali in the Singaraja area, as well as some employees who had left the company, (3) questionnaires, are data collection carried out through the dissemination of statements compiled in a collection of statements to respondents by using a Likert scale.

The data analysis technique in this study used Path Analysis. This analysis was used to determine the magnitude of the total influence of the direct and indirect effects of job insecurity variables on turnover intention through job satisfaction on PT Telkom employees Access the Singaraja area. 


\section{Result and Discussion}

Based on the results of calculation of Path Analysis statistics using the Statistical Product and Service Solutions (SPSS) program 17.0 for Windows, the SPSS calculation, the results obtained could be illustrated in Figure 1.

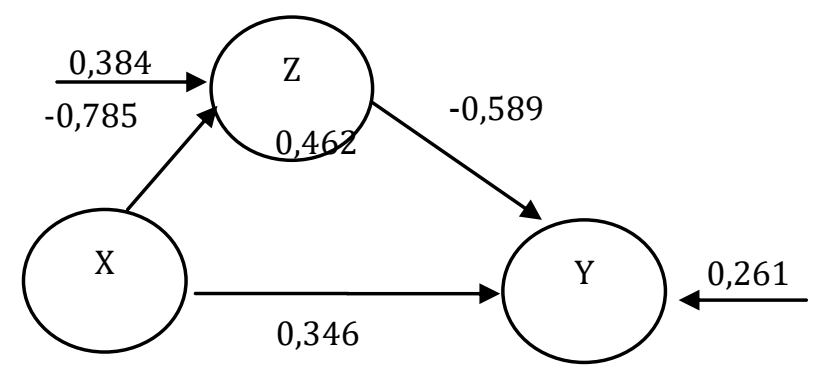

Figure 1. Effect of variable $\mathrm{X}$ on $\mathrm{Y}$ through $\mathrm{Z}$

The magnitude of the contribution of direct and indirect effects of job insecurity (X) toward turnover intention (Y) through job satisfaction (Z) in this study can be seen in Table 2.

Table 2. Donations for the Effect of Variable X on Y through Z

\begin{tabular}{lcc}
\hline \multicolumn{1}{c}{ Assertion } & Number of effect & Percentage \\
\hline Direct effect X toward Z & 0,616 & $61,60 \%$ \\
Direct effect X toward Y & 0,119 & $11,90 \%$ \\
Direct effect Z toward Y & 0,346 & $34,60 \%$ \\
indirect variabel effect Z mediate variabel X toward Y & 0,462 & $46,20 \%$ \\
Total effect of variabel X toward Y & 0,581 & $58,10 \%$ \\
Total effect of variabel X and Z toward Y & 0,739 & $73,90 \%$ \\
Other effect toward Y & 0,261 & $26,10 \%$ \\
Other effect toward Z & 0,384 & $38,40 \%$ \\
\hline
\end{tabular}

Based on the results of the Path Analysis Analysis statistic test, the results of the effect of job insecurity variables on turnover intention were obtained through job satisfaction on employees of PT Telkom Access Singaraja area could be seen as follows.

(1) Pyz Pzx $=0.462$ means that the indirect effect of variable $X$ on $Y$ is greater than the direct effect of variable X on $\mathrm{Y}$, which is equal to 0.346 . This means that the hypothesis (Ho) that states Pyz $<$ Pyx Pzx is rejected or the hypothesis (Ha) is accepted which states that variable $\mathrm{Z}$ can mediate variable $\mathrm{X}$ to $\mathrm{Y}$.

Mediation Effect Testing:

Hair et al (in Sholihin and Ratmono, 2013) Variance Accounted For (VAF) values were used to determine whether the connecting variable was able to mediate in full, partial or cannot mediate. If the FAV value was above $80 \%$, then it showed the full mediation role, if the FAV value ranged from $20 \%$ to $80 \%$ it was categorized as partial mediation, but if the FAV value was less than $20 \%$, it could be concluded that there was no mediation.

$$
\begin{aligned}
\mathrm{VAF} & =\frac{0,462}{0,346+0,462}=0,571 \\
& =57,10 \%
\end{aligned}
$$

The FAV value obtained is 0.571 or $57.10 \%$ ranging from $20 \%$ to $80 \%$, so the $\mathrm{Z}$ variable can be categorized as partial mediation.

(2) Pzx $=-0,785$ means that the influence of $X$ on $\mathrm{Z}$ is not equal to 0 . This means the hypothesis (Ho) which states $\mathrm{Pzx}=0$ is rejected or the hypothesis $(\mathrm{Ha})$ is accepted which states there is a relationship between $\mathrm{X}$ and $\mathrm{Z}$. Coefficient $\mathrm{PzX}=-0.785$ has a negative sign, which means that if $\mathrm{X}$ increases by one unit it will affect the change of $\mathrm{Z}$ in the opposite amount of -0.785 . P-value $<0.05$ means that the influence of job insecurity on job satisfaction is significant at $78.5 \%$, while the large contribution of the effect of job 
insecurity on job satisfaction is $\mathrm{P} 2 \mathrm{zx}=0.616$ or $61.60 \%$, while the influence of other factors on job satisfaction is large. amounting to 0.384 or $38.40 \%$.

(3) Pyx $=0.346$ means that the effect of the influence of X on $Y$ is not equal to 0 . This means the hypothesis (Ho) which states $\mathrm{Pyx}=0$ is rejected or the hypothesis (Ha) is accepted which states there is a relationship between $\mathrm{X}$ and $\mathrm{Y}$. Pyx coefficient $=0.346$ marked positive which means if $\mathrm{X}$ increases by one unit it will affect $Y$ change in a direction equal to 0.346 . P-value $<0.05$ means that the influence of job insecurity on turnover intention is significant at $34.60 \%$, while the large contribution of the effect of job insecurity on turnover intention is $\mathrm{P} 2 \mathrm{yx}=0.119$ or $11.90 \%$.

(4) Pyz $=-0,589$ means that the influence of $Z$ on $Y$ is not equal to 0 . This means that the hypothesis (Ho) which states Pyz $=0$ is rejected or the hypothesis (Ha) is accepted which states that there is a relationship between $\mathrm{Z}$ and Y. 0.589 has a negative sign which means if $\mathrm{Z}$ increases by one unit it will affect the $\mathrm{Y}$ change in the opposite amount of 0.589 . P-value $<0.05$ means that the influence of job satisfaction on turnover intention is significant at $58.90 \%$, while the contribution of job satisfaction to turnover intention is $\mathrm{P} 2 \mathrm{yz}=0.346$ or $34.60 \%$.

(5) The effect of total X and Z on Y (Ryzx) is 0.860 or $86 \%$. The contribution of job insecurity and job satisfaction on turnover intention on employee performance is 0.739 or $73.90 \%$, while the influence of other factors on turnover intention is $26.10 \%$.

Based on the research that has been done, the findings obtained that the variable job satisfaction was able to mediate in a timely manner the effect of job insecurity on turnover intention on employees of PT Telkom Access the Singaraja area. The results of this study were in line with the theory of Sverke et al (2014) in the short term job insecurity had an effect on job satisfaction and in the long run will have an effect on turnover intention. An empirical study that also supported the findings of this study was a study conducted by Setiawan (2016) who obtained results that partially job satisfaction could mediate the effect of job insecurity on turnover intention on employees of Legian village hotel. This was also in line with the research conducted by Devi (2015) on her research on contract employees at Bali Dynasty Resort revealing that job satisfaction played a role in job insecurity affecting turnover intention both directly and indirectly. If the problem of job insecurity continues to be faced by employees, it will affect employee job satisfaction and if it continues to occur it will stimulate the emergence of a desire to move work or turnover intention.

The subsequent findings obtained from the results of job insecurity variables have a negative and significant effect on job satisfaction on the employees of PT Telkom Access the Singaraja area. The results of this study were in line with the theory of Sverke et al (2014) according to which job insecurity had an effect on increasing employee dissatisfaction at work. The empirical study that supported this research was research conducted by Nurhadi (2017) which stated that job insecurity has a negative and significant effect on job satisfaction at PT Karya Mitra Budi Sentosa. This was also in line with the research conducted by Yasadipura (2017) which stated that job insecurity has a negative and significant effect on job satisfaction on PT Contract Employees, Wico Interna, Singaraja-Bali. If employees have high job insecurity, employee job satisfaction will decrease. Employees who have job insecurity towards the continuity of their work tend to feel dissatisfied compared to those who feel the certainty of the future of their work

The further findings obtained from the results of job insecurity variables have a positive and significant effect on turnover intention on employees of PT Telkom Access the Singaraja area. These findings were in line with the theory of Suhartono (2007: 61). If employees who experience job insecurity are increasing because of the instability of their employment status as contract employees can trigger high turnover intention (employee desires) that occur in a company. This was also in line with the theory of Mudiartha et al. (2001: 252), if work conditions are not safe, there will be a high turnover intention. The empirical study that supports the findings of this study is the result of a study conducted by Hanafiah (2014) wherein the research found that work insecurity has a positive and significant effect on the intention to move to work at PT. Buma Suara Village, Sambaliung District, Berau District. This is in line with the research conducted by Septiari (2017) which stated that job insecurity has a positive and significant effect on employee turnover at Hotel Asana Agung Putra Bali. Job insecurity is a very important job guarantee, the higher job insecurity, the higher turnover intention.

The further findings obtained by the results of the job satisfaction variable have a negative and significant effect on turnover intention on the employee of PT Telkom Access in Singaraja area. These findings were in line with Martoyo's theory (2007: 77). One of the things that influence employees' intention to leave the organization is the level of job satisfaction. Employees who have low job satisfaction will have an impact on turnover intention. This is also in line with the theory of Robbins and Timothy (2015: 54) who said that lower job satisfaction is a predictor for leaving work. The empirical study that supportes the findings of this study is the result of a study conducted by Hanafiah (2014) wherein the research found results that job satisfaction negatively and significantly affected the intention to move 
work to employees of PT. Buma Suara Village, Sambaliung District, Berau District. This is in line with the research conducted by Prabawa (2017) which states job satisfaction has a negative and significant effect on turnover intention at Grand Mirage Resort \& Thalasso Bali. Employees who have low job satisfaction will have a high desire to leave the company, conversely if employees have high job satisfaction, employees will have the desire to stay in the company.

\section{Conclusion}

Berdasarkan Based on the results of research and discussion that has been explained, it could be concluded as follows:

1. Job satisfaction could partially mediate the effect of job insecurity on turnover intention on employees of PT Telkom Access Singaraja area. This indicated that the effect of job insecurity on turnover intention could be partially mediated through employee job satisfaction.

2. Job insecurity had a negative and significant effect on job satisfaction on employees of PT Telkom Access Singaraja area. This indicated that the higher job insecurity felt by employees, the lower job satisfaction of employees.

3. Job insecurity had a positive and significant effect on turnover intention on employees of PT Telkom Access the Singaraja area. This indicated that the higher the job insecurity felt by employees, the higher the turnover of intention to employees.

4. Job satisfaction had a negative and significant effect on turnover intention on the employee of PT Telkom Access Singaraja area. This indicated that the higher the job satisfaction perceived by employees, the lower the turnover of intention to employees.

Based on the results of research, discussion and conclusions that has been stated, suggestions can be conveyed to the management of PT Telkom Singaraja Access area which is in reducing turnover intention level is expected to pay more attention to job insecurity and job satisfaction because research proves that job insecurity and job satisfaction affect turnover intention.

\section{Reference}

Alfresia, Prischa. 2016. Pengaruh Kepuasan Kerja dan Komitmen Organisasi Terhadap Turnover intention Karyawan (Studi pada PT Kajima Indonesia). Skripsi. Program Studi Manajemen Fakultas Ekonomi Universitas Negeri Yogyakarta.

Burchell, Brendan., D. Ladipo dan F. Wilkinson. 2002. Job insecurity and Work Intensification. New York: Routledge.

Devi, Sri. 2015. Analisis Pengaruh Job Insecurity, Dan Kompensasi Finansialterhadap Kepuasan Kerja Dan Turnover Intention: (Studi Pada Karyawan Kontrak Di Bali Dynasty Resort). E-Jurnal Manajemen Unud, Vol. 4, No. 4, 2015:1047-1066 ISSN: 2302-8912.

Elmi, Farida. 2018. Telisik Manajemen Sumber Daya Manusia. Jakarta: Mitra Wecana Media.

Hanafiah, Mohammad. 2014. Pengaruh Kepuasan Kerja Dan Ketidakamanan Kerja (Job Insecurity) Dengan Intensi Pindah Kerja (Turnover Intention) Pada Karyawan PT. Buma Desa Suara Kecamatan Sambaliung Kabupaten Berau. E- Jurnal Psikologi, 1(3) : 303-312.

Harnoto. 2002. Manajemen Sumber Daya Manusia. Jakarta: Prehallindo.

Luthans, Fred. 2006. Perilaku Organisasi. Yogyakarta: ANDI.

Martoyo, Susilo. 2007. Manajemen Sumber Daya Manusia. Yogyakarta: BPFE.

Mobley,W. H. 2011. Pergantian Karyawan: Sebab, Akibat dan Pengendaliannya (Terjemahan). Jakarta: PT Pustaka Binaman Pressindo.

Mudiartha Utama, I Wayan. 2001. Manajemen Sumber Daya Manusia. Denpasar UPT. Penerbit: Universitas Udayana. 
Nurhadi, Pandi. 2017. Hubungan antara job Satisfaction dengan job insecurity pada karyawan. Skripsi. Program Studi Psikologi Fakultas Psikologi dan Kesehatan Universitas Islam Negeri Sunan Ampel Surabaya.

Prabawa, Yogi. 2017. "Pengaruh Ketidakamanan Kerja, Kepuasan Kerja dan Komitmen Organisasional terhadap Turnover Intention Pada Grand Mirage Resort \& Thalasso Bali". E-Jurnal Manajemen Unud, Vol. 6, No. 12, ISSN : 2302-8912.

Robbins, Stephen P. Judge, Timothy A. 2015. Perilaku Organisasi. Jakarta: Salemba Empat.

Septiari. 2016. "Pengaruh Job Insecurity dan Stres Kerja terhadap Turnover Intention Karyawan pada Hotel Asana Agung Putra Bali". E-Jurnal Manajemen Unud, Vol. 5, No. 10, ISSN: 2302-8912.

Setiawan, Agus. 2016. "Pengaruh Job Insecurity dan Stres Kerja turnover Intention Karyawan pada Hotel Asana Agung Putra Bali”. E-Jurnal Manajemen Unud, Vol. 5, No. 10, ISSN: 2302-8912.

Sholihin, M. Ratmono, D. 2013. Analisis SEM-PLS dengan WarpPLS 3.0. Yogyakarta: ANDI.

Simamora, H. 2004. Manajemen Sumber Daya Manusia. Yogyakarta: STIE YKPN.

Sugiyono. 2014. Metode Penelitian Bisnis (Pendekatan Kuantitatif, Kualitatif, dan R\&D). Bandung: Alfabeta.

Suhartono. 2007. Manajemen Sumber Daya Manusia. Jakarta: Lembaga Penerbit Fakultas Ekonomi Universitas Indonesia.

Sunyoto, Danang. 2012. Manajemen Sumber Daya Manusia. Yogyakarta: CAPS (Center for Academic Publishing Service).

Sverke, Magnus. et al. 2004. Job insecurity and Union Membership European Unions in the Wake of Flexible Production. Brusel: P.I.E,-Peter Lang S.A.

Wibowo. 2014. Perilaku Dalam Organisasi. Jakarta. Rajawali Pers.

Yasadiputra, Aris. 2017. "Pengaruh Organizational Justice serta Job Insecurity terhadap Job Satisfaction Pegawai Kontrak pada Pt. Wico Interna, Singaraja-Bali”. Jurnal Manajemen Strategi Bisnis dan Kewirausahaan Fakultas Ekonomi dan Bisnis Universitas Udayana (UNUD). Vol. 8, No. 1. 